\title{
Aluminum alloys welding with micro-jet cooling in busducts
}

\begin{abstract}
Aluminium alloys were used in many structural applications, including the civil engineering field. The innovative technology of welding with micro-jet cooling was tested and the effects were reported. The main information is given on the parameters of aluminum welding with the micro-jet cooling process. Information was also reported on the influence of various micro-jet parameters on the metallographic structure. Subsequently, metallographic and certain physical properties of welding structures (for example, mechanical resistance, electrical conductivity) were tested. Aluminum alloys are lightweight and resistant to corrosion in the natural and aquatic environment, which is why they are a suitable material for responsible structures (in the construction of ships, vehicles, electrical conductors). This article focuses on the mechanical and electrical properties of busduct welds made with the micro-jet cooling pioneering technology.
\end{abstract}

Keywords: welding; micro-jet cooling; metallographic structure; civil engineering, mechanical resistance; conductivity

\section{Introduction}

Busducts are elements which conduct electricity, usually of large dimensions (lengths of up to several dozen meters, with external diameters of up to $2000 \mathrm{~mm}$ ), typically used for transferring high-value current. They are mostly used as an interconnection between generators and step-up transformers in all kinds of power plants worldwide. Busducts are structures with a conductor (typically round-shaped) supported on post insulators and enclosed in a round-shaped enclosure. Due to its production process, a busduct is welded between each production segment (typically it's round welded every $1500 \mathrm{~mm}$ ) and has got a longitudinal weld [1].

Busbars are divided into (Fig. 1):

1. Insulated phase busducts (with isolated phases),

2. Non-segregated phase busducts,

3. Segregated phase busducts.

In the production process of busducts, one of the most important things is the quality of the welded joints. The reason for this is their critical role in the mechanical strength of busducts as well as their electrical parameters. In the case of a short-circuit fault in the system, electrodynamic forces will appear, which will affect the busduct elements, especially the welded joints in the non-linear elements (busduct elbows) [3]. Currently, in order to prevent the possible effects of short circuits, special solutions are used to counteract

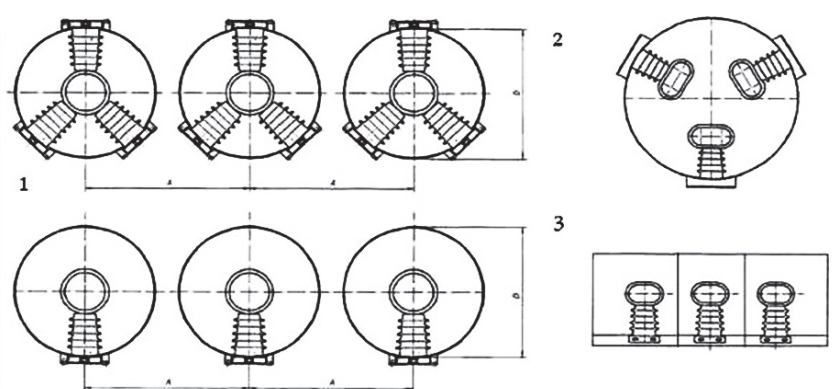

Fig. 1. Aluminum alloy busduct, which must have good mechanical properties and high electrical conductivity [2]

the forces affecting weld joints in the event of an emergency. Examples of such solutions include additional support insulators, or the use of more durable (more expensive) material for the production of busducts. What is important to understand is that if a welded joint is damaged in a busduct, the whole power unit must be stopped, cutting it from the national electrical grid so that proper maintenance can be conducted for a certain period of time, which means a significant loss of profits for power plant operators [4].

Another factor that must be taken into consideration is the environmental factor. During the normal operation of a busduct, heat is generated, known as power losses of a power

dr hab. inż. Bożena Szczucka-Lasota, prof. PŚl; prof. dr hab. inż. Tomasz Węgrzyn - Silesian University of Technology, Poland mgr inż. Michał Krzysztoforski - Elektrobudowa

Corresponding author: bozena.szczucka-lasota@polsl.pl 
unit [5]. Improvement of the electrical parameters (an increase in conductivity) of welded joints will result in a decrease of thermal losses, which will directly result in a reduction of electricity demand and thus a reduction in the fuel demand necessary to run a power unit. By improving the electrical parameters of welded joints, negative effects to the environment caused by power plants are reduced.

Rapid progress in modern industries, including welding, depended mostly on the capabilities of forming materials and surface engineering $[6 \div 9]$.

The goal of the study was to examine the varying structure and properties for power energy purposes of a typical MIG (Metal Inert Gas Welding) process with innovative micro-jet cooling. For the first time, an attempt was made to weld aluminum alloys using micro-jet cooling. The most popular aluminum alloys in the industry are Al-Mn (3XXX group), Al-Si (4XXX group), Al-Mg (5XXX group) and Al-Mg-Si (6XXX group), mainly due to their excellent corrosion resistance and good weldability. The most commonly used alloys for welded constructions are alloys 5052, 5154, 5454, 5083 and 6061. The best filler material for welding those alloys is 5356 . The type of filler material used in aluminum welding is an important factor that can influence the mechanical properties, most notably eliminating cracking. Cracking usually can be minimized by using welding filler wire of a lower amount of $\mathrm{Si}$ and $\mathrm{Mg}$ than in base metal [10]. For example, crack-sensitive alloys 6060 and 6061 should be welded with 4043, 5183 or 5356 filler material, which have a lower amount of $\mathrm{Si}$ and $\mathrm{Mg}$ [11]. This decreases crack sensitivity, without changing weld strengths [12]. The same principle is used for welding alloys Al-Li, group 8xxxx, where the Li content in the electrode wires is limited [13]. The most popular aluminum alloys (especially for power energy needs) are 6060, 6082, 5251 due to their good corrosion resistance, excellent conductivity and good weldability. There are serious difficulties in welding Al-Cu (2XXX group) and Al-Zn (7XXX group) due to the occurrence of cracks [14]. These unweldable alloys can result not only in cracking, but they are also known for their premature failure in service at a later time. There are some exceptions in this group. For example, the 2219, 2519, $7003,7004,7005$ and 7039 alloys are known for their good weldability [15]. Almost all of the alloys in the 1XXX, 3XXX, $4 X X X, 5 X X X$ and $6 X X X$ groups can be properly welded using the TIG and MIG processes [11]. The main goal of the project is to check the applicability of the innovative method of micro-jet cooling in aluminum busduct welding. Busducts are known for their use in large constructions for power energy needs (Fig. 2).

Welding with micro-jet technology was first tested for steel welding in 2013 at the ISOPE congress in Alaska [16].

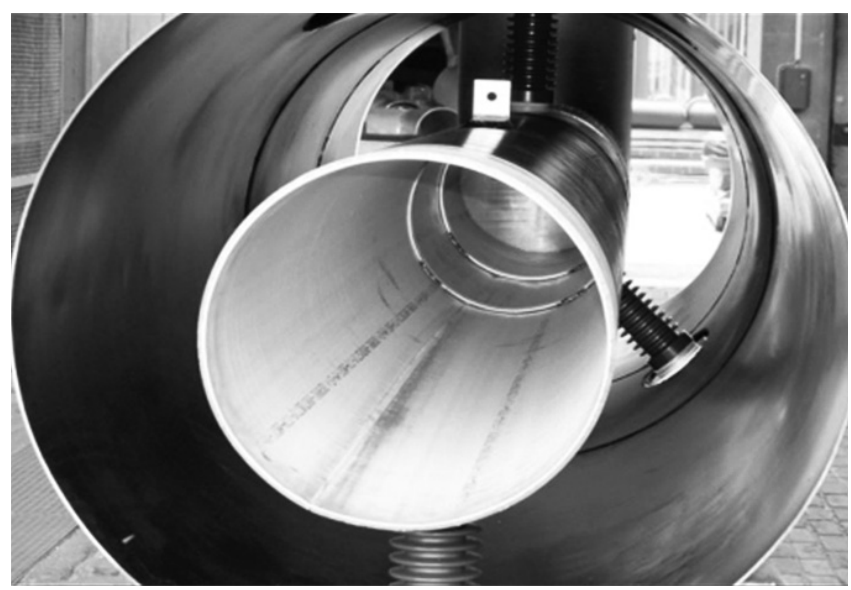

Fig. 2. Aluminum alloy busduct, which must have good mechanical properties and high electrical conductivity [2]
Surface welding was successfully presented in 2016 in the publication [17]. It is, therefore, a very new and not fully finished process. In the case of low alloy steel welding, very favourable mechanical properties were obtained using micro-jet cooling, because of the artificially lifted high amount of fine ferrite [18]. The use of micro-jet cooling has brought great benefits in low alloy steel welding, as the high acicular ferrite content (impossible to obtain in classical processes) translated to a high impact toughness at sub-zero temperatures. In the case of steel hardfacing, very favourable mechanical properties were obtained due to nitrogen micro-jet cooling because of a noticeable strengthening of the solution with nitrogen and lifting the martensitic percentage and even obtaining nitrides [19]. This increased the hardness in the coating and the resistance to abrasive wear [19]. In the case of aluminum alloy welding, grain fragmentation is important, which translates into better mechanical properties and presumably better electrical conductivity of the weld and surface weld.

The most important factors of micro-jet cooling after the welding process are $[16,17]$ :

- diameter of the stream of the micro-jet injector,

- type of micro-jet gas or gas mixture,

- micro-jet gas pressure,

- the number of jets.

\section{Experimental procedure}

A test stand for welding was made in order to check the properties of aluminum alloys after welding using the MIG method with micro-jet cooling (Fig. 3). A micro-jet injector was installed with a variable number of micro-streams $(1 \div 3)$.

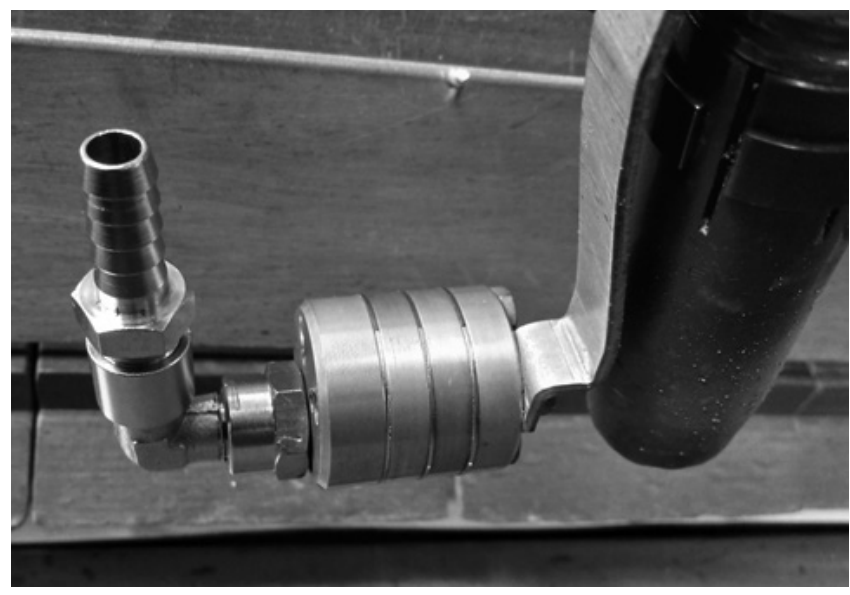

Fig. 3. Test stand for aluminum welding with micro-jet cooling

Two micro-jet gases (argon, helium) were tested in the cooling process just after surface welding. Two other important micro-jet parameters were also varied: micro-jet gas pressure and micro-jet stream diameter. The diameter of streams was at a level of $50 \mu \mathrm{m}$ and $60 \mu \mathrm{m}$. Micro-jet gas pressure was varied twice: $0.4 \mathrm{MPa}$ and $0.5 \mathrm{MPa}$. Welds were made with different variants of the MIG process parameters (welding speed, voltage, wire feed, current). Wire 4043 (with 5\% of $\mathrm{Si}, 0.1 \% \mathrm{Cu}, 0.01 \% \mathrm{Mn}$ ) were used in all welding tests. The weldability of the busduct material with two different welding speeds was tested. The main data about the parameters of welding are shown in Table I.

The properties of aluminum (6082 T651) busduct welds were checked using micro-jet cooling after the welding process. This alloy is typically subject to a solubilization at $\sim 529^{\circ} \mathrm{C}$ and aging at $\sim 170^{\circ} \mathrm{C}$. Also, the chemical composition 
of 6082 alloy is characterized by the addition of a low amount of $\mathrm{Si}, \mathrm{Mn}, \mathrm{Mg}$, Fe. The chemical composition of 6082 T651 alloy is presented in Table II.

Argon and helium were chosen for micro-jet cooling because of their significantly various cooling conditions. This is due to different conductivity coefficients $(\lambda)$, which for $\mathrm{Ar}$ in the $273 \mathrm{~K}$ is at a level of $23.74 \mathrm{~J} / \mathrm{cm} \cdot \mathrm{s} \cdot \mathrm{K}$. Helium gives much stronger cooling conditions due to higher conductivity coefficients $(\lambda)$, which is $143.4 \mathrm{~J} / \mathrm{cm} \cdot \mathrm{s} \cdot \mathrm{K}$.

\section{Results and discussion}

The aim of the study was to examine the structure and various properties of aluminum alloy 6082 T651 (a typical material used in busduct structures for power energy purposes) after the MIG process with micro-jet cooling. First

Table I. Parameters of the MIG welding process with micro-jet cooling

\begin{tabular}{|c|c|c|}
\hline Comments & Parameter & Value \\
\hline & diameter of wire (4043) & $1.2 \mathrm{~mm}$ \\
\hline $\begin{array}{l}\text { high } \\
\text { welding } \\
\text { speed }\end{array}$ & $\begin{array}{l}\text { standard current } \\
\text { welding speed } \\
\text { voltage } \\
\text { wire feed }\end{array}$ & $\begin{array}{c}235 \mathrm{~A} \\
700 \mathrm{~mm} / \mathrm{min} \\
25.5 \mathrm{~V} \\
11.1 \mathrm{~m} / \mathrm{min}\end{array}$ \\
\hline \multirow[t]{7}{*}{$\begin{array}{c}\text { low } \\
\text { welding } \\
\text { speed }\end{array}$} & $\begin{array}{l}\text { standard current } \\
\text { welding speed } \\
\text { voltage } \\
\text { wire feed }\end{array}$ & $\begin{array}{c}235 \mathrm{~A} \\
300 \mathrm{~mm} / \mathrm{min} \\
23.8 \mathrm{~V} \\
11.1 \mathrm{~m} / \mathrm{min}\end{array}$ \\
\hline & shielding welding gas & $\mathrm{Ar}$ \\
\hline & micro-jet cooling gases & Ar or $\mathrm{He}$ \\
\hline & micro-jet gas pressure & $\begin{array}{c}0.4 \mathrm{MPa} \\
\text { or } 0.5 \mathrm{MPa}\end{array}$ \\
\hline & micro-jet diameter & $50 \mu \mathrm{m}$ or $60 \mu \mathrm{m}$ \\
\hline & $\begin{array}{l}\text { inclination of cooling stream } \\
\text { relative to the weld or coating }\end{array}$ & perpendicularity \\
\hline & $\begin{array}{l}\text { distance between welding } \\
\text { head and injector }\end{array}$ & $40 \mathrm{~mm}$ \\
\hline
\end{tabular}

Table II. Aluminum alloy used for the weldability test after micro-jet cooling

\begin{tabular}{|c|c|}
\hline Al alloy & Chemical composition \\
\hline $6082 \mathrm{~T} 651$ & $1 \% \mathrm{Si} ; 03 \% \mathrm{Fe} ; 0.1 \% \mathrm{Mn} ; 0.6 \% \mathrm{Mg}$ \\
\hline
\end{tabular}

it was decided to examine and evaluate the results of the bending test of aluminum joints welded using the MIG process with micro-jet cooling and without any kind of cooling. After obtaining this information, a decision was made to examine the effects of micro-jet cooling on the metallographic structure of the welds. The next stage of the research was the assessment of the tensile strength of aluminum MIG joints with micro-jet cooling and without cooling. Then, the electrical conductivity of the aluminum busducts (huge connectors), using the MIG process with micro-jet cooling and without cooling, was evaluated, as electrical conductivity is the most important parameter of the materials used to build busducts. Alloy 6082 T651 is commonly used for the construction of busducts.

Basic information about good plastic properties of welds can be obtained after bending. The cross-section of the bending test specimens was $5 \times 20 \mathrm{~mm}$. The bending mandrel had a diameter of $45 \mathrm{~mm}$. The bend angle was $180^{\circ} \mathrm{C}$. Five samples were used in each test according to EN ISO 5173:2010 standards. The samples were bent from the side of the weld face (WF) and the weld root (WR). The weldability of 6082 T651 alloy with two different welding speeds was tested (value from Tab. I). A change in welding speed has an effect on the cooling time of the weld, which translates into a change in the metallographic structure. This is very noticeable for steel welding; however, aluminum alloys can also be effected on the structure by changing the welding conditions. The results of the bending tests are presented in Table III (higher welding speed) and Table IV (lower welding speed).

Tables III, IV show that micro-jet cooling improves the plastic properties because it prevents cracks from forming in the joint. The right choice of micro-jet cooling parameters is important. Helium is a more intensive cooling gas than argon, thus cracking occurred when helium was used as a micro-jet gas and when cooling was carried out in a way that was too intense. Bending tests clearly show that argon micro-jet cooling is essential in welding tested aluminum alloys.

Table III. Bending test results of aluminum alloy 6082 T651 after welding with micro-jet cooling (higher speed of the welding process)

\begin{tabular}{|c|c|c|c|c|}
\hline Process & $\begin{array}{l}\text { Type of micro-jet } \\
\text { cooling gas }\end{array}$ & $\begin{array}{l}\text { Micro-jet gas } \\
\text { pressure, MPa }\end{array}$ & $\begin{array}{c}\text { Micro-jet } \\
\text { diameter, } \mu \mathrm{m}\end{array}$ & Observation \\
\hline MIG without micro-jet cooling & - & & & $\begin{array}{l}\text { traces of cracks after bending from the side } \\
\text { of WR and WF }\end{array}$ \\
\hline MIG with micro-jet cooling & $\mathrm{He}$ & 0.4 & 50 & traces of cracks from the side of WR \\
\hline MIG without micro-jet cooling & $\mathrm{He}$ & 0.4 & 60 & traces of cracks from the side of WR \\
\hline MIG with micro-jet cooling & $\mathrm{He}$ & 0.5 & 50 & traces of cracks from the side of WR \\
\hline MIG with micro-jet cooling & $\mathrm{He}$ & 0.5 & 60 & traces of cracks from the side of WR \\
\hline MIG without micro-jet cooling & $\operatorname{Ar}$ & 0.4 & 50 & no cracks \\
\hline MIG with micro-jet cooling & $\mathrm{Ar}$ & 0.4 & 60 & no cracks \\
\hline MIG without micro-jet cooling & $\mathrm{Ar}$ & 0.5 & 50 & no cracks \\
\hline MIG with micro-jet cooling & $\mathrm{Ar}$ & 0.5 & 60 & traces of cracks from the side of WR \\
\hline
\end{tabular}




\begin{tabular}{|c|c|c|c|c|}
\hline Process & $\begin{array}{l}\text { Type of micro-jet } \\
\text { cooling gas }\end{array}$ & $\begin{array}{l}\text { Micro-jet gas } \\
\text { pressure, MPa }\end{array}$ & $\begin{array}{l}\text { Micro-jet diam- } \\
\quad \text { eter, } \mu \mathrm{m}\end{array}$ & Observation \\
\hline MIG without micro-jet cooling & - & - & - & $\begin{array}{l}\text { traces of cracks after bending from the side } \\
\text { of WR and WF }\end{array}$ \\
\hline MIG with micro-jet cooling & $\mathrm{He}$ & 0.4 & 50 & traces of cracks from the side of WR \\
\hline MIG without micro-jet cooling & $\mathrm{He}$ & 0.4 & 60 & no cracks \\
\hline MIG with micro-jet cooling & $\mathrm{He}$ & 0.5 & 50 & no cracks \\
\hline MIG with micro-jet cooling & $\mathrm{He}$ & 0.5 & 60 & no cracks \\
\hline MIG without micro-jet cooling & $\mathrm{Ar}$ & 0.4 & 50 & no cracks \\
\hline MIG with micro-jet cooling & $\mathrm{Ar}$ & 0.4 & 60 & no cracks \\
\hline MIG without micro-jet cooling & $\mathrm{Ar}$ & 0.5 & 50 & no cracks \\
\hline MIG with micro-jet cooling & $\mathrm{Ar}$ & 0.5 & 60 & traces of cracks from the side of WR \\
\hline
\end{tabular}

One can observe that a slower welding speed is more favourable. It may be related to the fact that a lower speed corresponds with the extended cooling time of the weld, which positively affects the plastic properties of the aluminum busduct joint. For further tests, only busduct welding with slower speeds was selected, but micro-jet cooling was further tested for both argon and helium.

More tests were carried out to determine what is the effect of micro-jet cooling on the metallographic structure of a joint. The type of micro-jet gas did not affect the metallographic metal structure of the weld metal deposit. Figure 4 shows the metallographic structure of a weld made using the MIG process without micro-jet cooling. Figure 5 shows the metallographic structure of a weld made using the MIG process and argon micro-jet cooling.

Analyzing Figures 4 and 5 gives us an opportunity to observe the fragmentation of the phases $\beta$ (Si) in the weld resulting from welding with micro-jet cooling, even by about $50 \%$, compared to the size of the $\beta$-phase grains in the weld resulting from welding without additional cooling. Precipitates were also observed (probably from the intermetallic phase base composition, $\mathrm{Al}_{3} \mathrm{Mg}_{2}$ ). The EDS analysis confirmed, that in the structure of weld were main elements such as: $\mathrm{Al}, \mathrm{Si}, \mathrm{Mg}$ and $\mathrm{Cu}$. By the scanning microscopy it was shown, that two other phases $\beta$ (Si) and $\mathrm{Al}_{3} \mathrm{Mg}_{2}$ on the grain

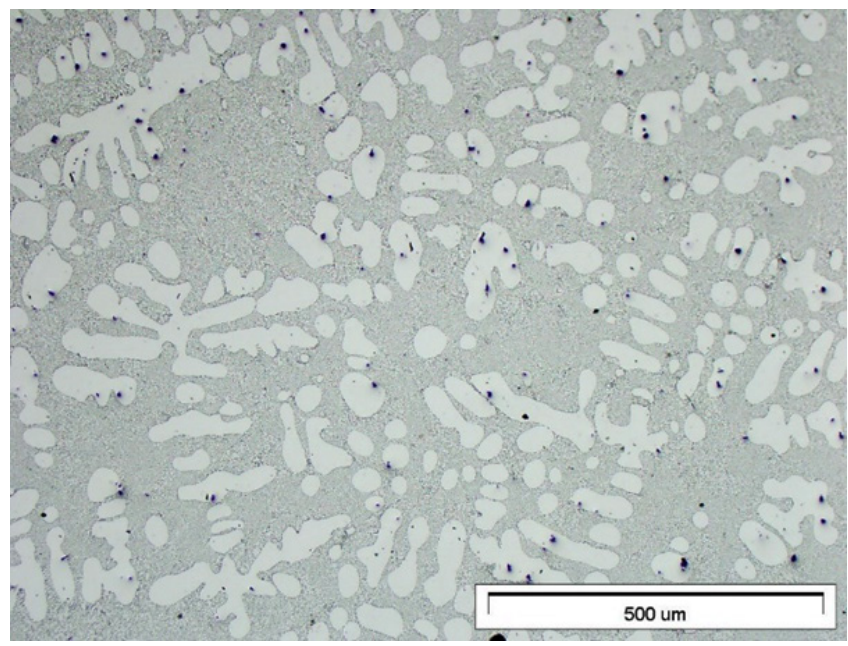

Fig. 4. The metallographic structure of an aluminum alloy 6082 T651 weld made using the MIG process without micro-jet cooling (LM - light microscopy) border are detected. The average size of grain in weld was on the level of $40 \mu \mathrm{m}$ (Fig. 6).

There were observed the spectra of Fe (base material alloy element) and $\mathrm{Cu}$ (wire alloy element). By the X-ray analysis method the other intermetallic apart from $\mathrm{Al}_{3} \mathrm{Mg}_{2}$ were not detected. The obtained diffraction are presented in the Figure 7. On the diffractions, it was observed the phases in weld metal deposit such as: $\mathrm{a}(\mathrm{Al}), \beta(\mathrm{Si})$ and $\mathrm{Al}_{3} \mathrm{Mg}_{2}$ (two last peaks correspond with $\mathrm{Al}_{3} \mathrm{Mg}_{2}$ phase).

Diffractograms (Fig. 8) of weld metal deposit taken in standard MIG process without micro-jet cooling is very similar.

The only difference is to find the presence of the brittle $\mathrm{Mg}_{2} \mathrm{Si}$ phase, which was not observed after MIG welding with micro-jet cooling. After this, the strength of the welded joints was checked (according to EN ISO 6892-1:2016-09) as well as the electrical properties of the welded and surface welded sheets. Tensile results show increase in both yield strength (fy) and ultimate tensile strength (fu) in the analysed welding processes (Tab. V).

In order to facilitate the interpretation of tabular data, it is presented below in the form of a graph (Fig. 9).

Strength and yield point are rather similar in the tested cases (various materials and cooling conditions), but the relative elongation always increases (because of the positive micro-jet cooling effect). By observing the elongation values,

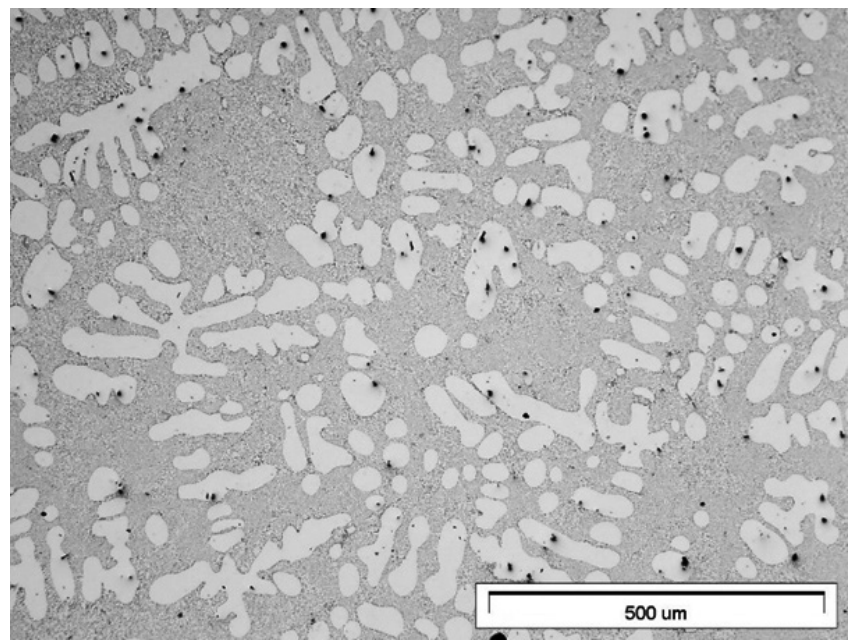

Fig. 5. The metallographic structure of an aluminum alloy 6082 T651 weld made using the MIG process with argon micro-jet cooling (LM - light microscopy) 

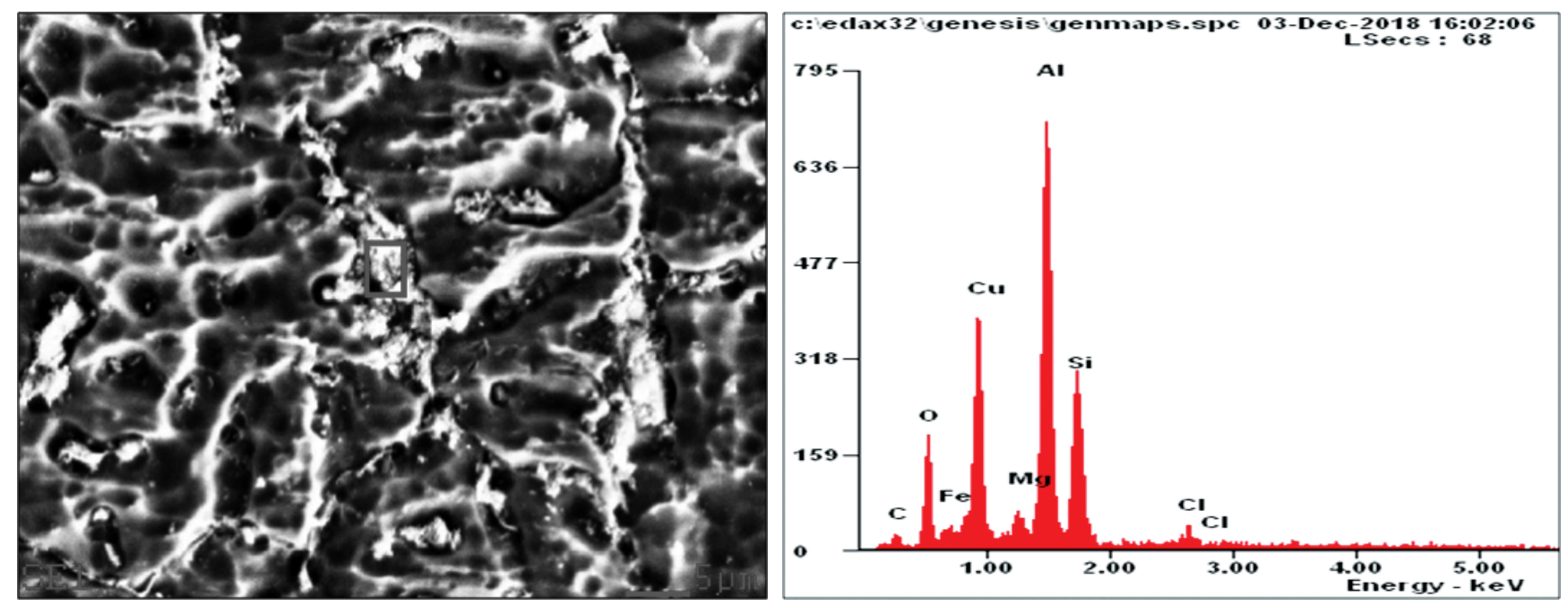

Fig. 6. The metallographic structure and EDS (Electron dispersive X-ray microscopy) analysis of an aluminum alloy 6082 T651 weld made using the MIG process with argon micro-jet cooling (SEM - scanning electron microscopy)

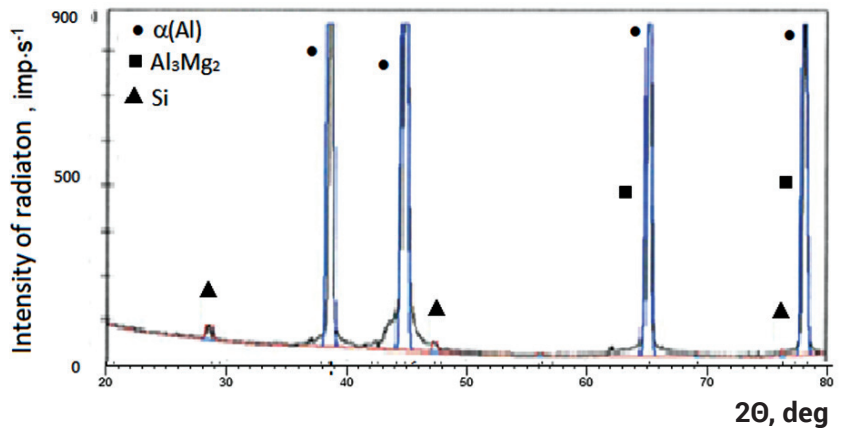

Fig. 7. The graphs of X-ray diffractograms (weld metal deposit after welding with micro-jet cooling)

it can be seen that argon is a more beneficial gas than helium for micro-jet cooling. Permanent deformation is clearly noticeable after MIG welding with direct micro-jet cooling.

The most important issue related to the construction of busducts is to provide (on this tubular construction) the best possible electrical conductivity. The SIGMATEST 2.069 is an eddy current instrument that measures the electrical conductivity of non-ferromagnetic metals based on the complex impedance of the measuring probe. The measuring range for the instrument is established by calibration. The conductivity tests were carried out in accordance with the manufacturer's SIGMATEST 2.069 precise instructions.

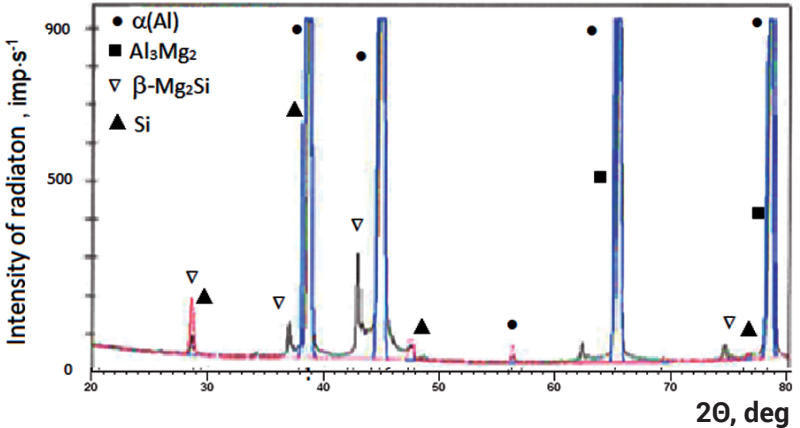

Fig. 8. The graphs of X-ray diffractograms (weld metal deposit after welding without micro-jet cooling)

The conductivity of alloy 6082 is very good (at a level of $35 \mathrm{MS} / \mathrm{m}$ ). A MIG welded connection lowers the electrical conductivity by half, to a level of $17 \mathrm{MS} / \mathrm{m}$. A decision was made to check whether grain refinement after welding with micro-jet cooling would increase the electrical conductivity of the conductor. The results of the electrical conductivity tests of the welded structure with and without the use of micro-jet cooling are presented in Table VI.

In order to facilitate the interpretation of tabular data, it is presented below in the form of a graph (Fig. 10).

It turned out that both micro-jet cooling with helium or argon greatly increases the conductivity of a welded alloy almost

Table V. Tensile results in the analysed aluminum alloy 6082 T651 welding processes of the MIG welding process with and without micro-jet cooling

\begin{tabular}{|c|c|c|c|c|c|}
\hline Welding process & $\begin{array}{l}\text { Micro-jet gas } \\
\text { pressure, MPa }\end{array}$ & $\begin{array}{c}\text { Micro-jet } \\
\text { diameter, } \mu \mathrm{m}\end{array}$ & Fy, MPa & $\mathrm{Fu}, \mathrm{MPa}$ & Elongation, \% \\
\hline MIG & - & - & 195 & 215 & 9 \\
\hline MIG with argon micro-jet cooling & 0.4 & 50 & 190 & 208 & 13 \\
\hline MIG with argon micro-jet cooling & 0.4 & 60 & 188 & 211 & 14 \\
\hline MIG with argon micro-jet cooling & 0.5 & 50 & 192 & 210 & 15 \\
\hline MIG with argon micro-jet cooling & 0.5 & 60 & 188 & 206 & 13 \\
\hline MIG with helium micro-jet cooling & 0.4 & 50 & 191 & 218 & 10 \\
\hline MIG with helium micro-jet cooling & 0.4 & 60 & 196 & 220 & 12 \\
\hline MIG with helium micro-jet cooling & 0.5 & 50 & 191 & 224 & 11 \\
\hline MIG with helium micro-jet cooling & 0.5 & 60 & 193 & 213 & 10 \\
\hline
\end{tabular}




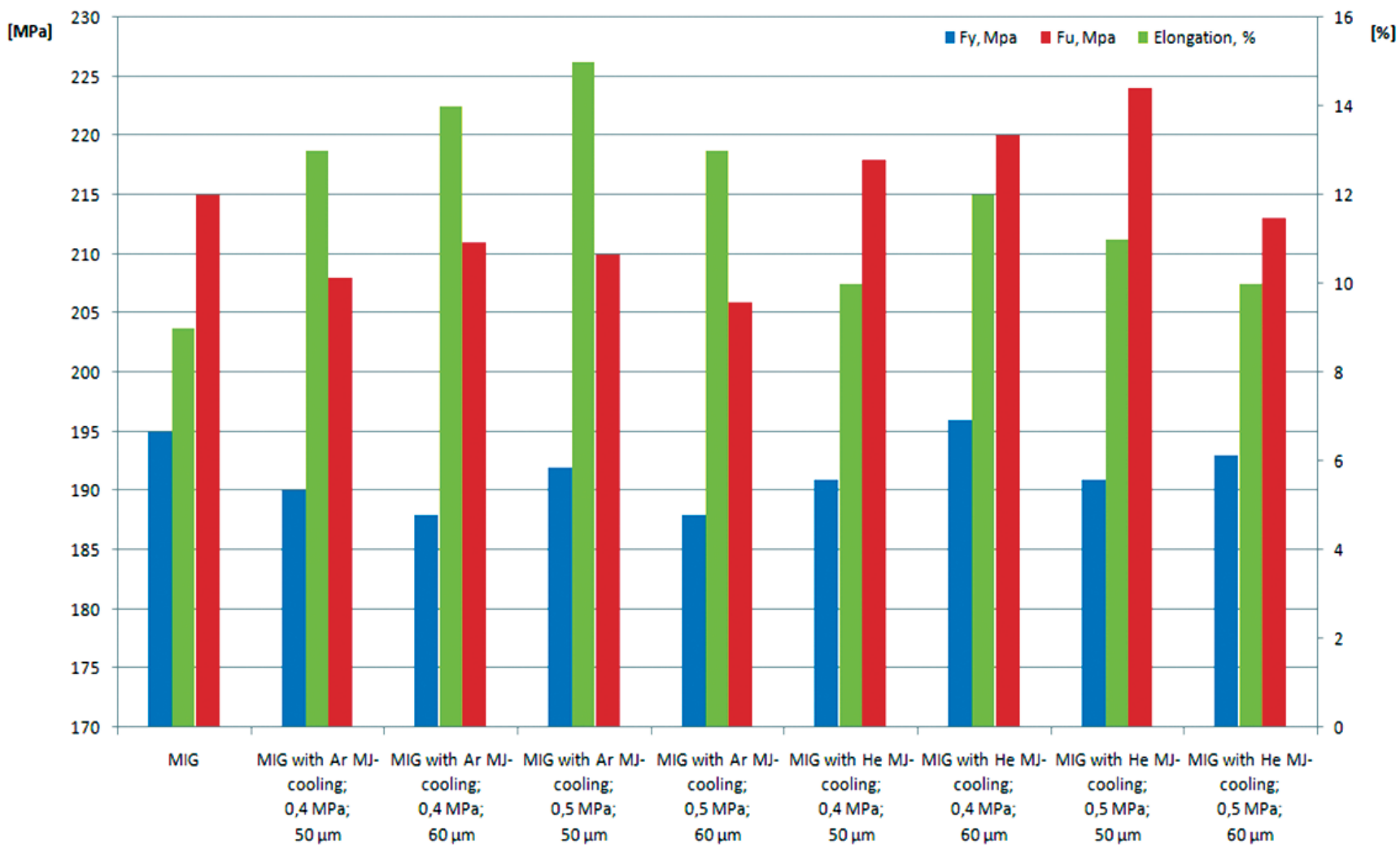

Fig. 9. Graphical representation of the mechanical properties of aluminum welds

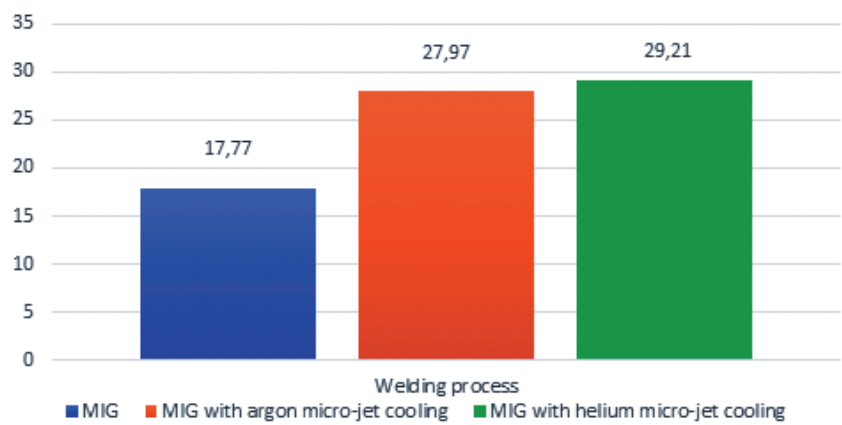

Fig. 10. Graphical representation of the conductivity of busduct elements made by various welding processes

to its value of a base material without welding (34 MS/m). The micro-jet gas does not have a significant influence on the conductivity of the alloy, although argon appears to be a more favourable gas. Micro-jet helium cooling guarantees the conductivity of busducts at a level of $28 \mathrm{MS} / \mathrm{m}$.
Micro-jet argon cooling guarantees the conductivity of busducts at a level of $29 \mathrm{MS} / \mathrm{m}$.

The analysis of the data in Table VI allows us to conclude that increased conductivity limits the thermal losses associated with the heating of busducts during current flow. At the same time, there is a second observation: to preserve the ability to conduct the same current, the busduct structure with a smaller cross-section may be proposed.

Table VI. Conductivity of busduct elements made by various weIding processes

\begin{tabular}{|c|c|}
\hline Welding process & $\begin{array}{c}\text { Electrical conductivity, } \\
\text { MS/m }\end{array}$ \\
\hline MIG & 17.77 \\
\hline MIG with argon micro-jet cooling & 27.97 \\
\hline MIG with helium micro-jet cooling & 29.21 \\
\hline
\end{tabular}

\section{Summary and conclusion}

The pioneering method of welding aluminum alloys using micro-jet cooling was conducted. Tests related to the welding of important civil engineering structure which are the busducts have been carried out. This type of construction must have good plastic properties and high electrical conductivity. Current welding processes do not guarantee good conductivity, often twice lower than aluminum alloy. Welding of busducts with two different welding speeds and with different micro-jet gases (helium, argon) was tested. Bending tests showed that a slower welding speed is more beneficial, as there is a longer cooling period by micro-jet gases (argon or helium). Better plastic properties were observed, which means a higher elongation value. Strength tests showed that after micro-jet welding, the busducts have a value that is comparable to welded joints without cooling. Two smaller grain refinement after welding using micro-jet cooling was noted. In this case, helium and argon during micro-jet cooling of the weld produced a similar effect. The most important observation associated with the use of micro-jet cooling is related to the electrical conductivity of the busduct (huge conductor). Micro-jet cooling allows us 
to obtain conductivity at the base material conductivity level (34 MS/m), while the classic MIG process reduces the conductivity of the connector by half $(17 \mathrm{MS} / \mathrm{m})$. On the basis of this research, the following conclusions can be drawn:

1. Micro-jet cooling leads to better mechanical properties after welding of busducts,

2. The most preferred micro-jet gas for 6082 alloy welding is argon,

3. Fragmentation of the $\beta$ phase (Si) (even by about $50 \%$ ) in the weld resulted from welding with micro-jet cooling,

4. Micro-jet cooling allows us to double the electrical conductivity of aluminum joints to the level of conductivity of the base material (34 MS/m).

5. The use of micro-jet cooling in aluminum alloys can result in large savings in responsible constructions for civil engieering on the busducts example due to the reduction of power losses.

\section{References}

[1] K.C. Agrawal, Industrial Power Engineering and Applications Handbook, Newnes Power Engineering Series, ISBN 978-0-7506-7351-8, Elsevier Inc. (2001), 31.

[2] D. Pytel, B. Szczucka-Lasota, M. Krzysztoforski, T. Węgrzyn, Logistics problems related to international sea transport of large loads on the example of busducts, Proceeedings of X International Scientific Conference, Transport Problems, Wisła, Silesian University of Technology, June (2018).

[3] G. Szymański, A. Patecki, Eddy current and temperature of the sheath in tree-phase pipe sheathing system, IEEB Transaction of magnetics (20042006), vol. MAG-20.

[4] B. Baron, Z. Piatek, Substitute impedance and current density in cylindrical conductors of a single phase high-current busduct, (W), Computer aide design of electroheat devices, Wydawnictwo Politechniki Śląskiej (2002), Gliwice, 252-265.

[5] IEEE Standard for Metal-Enclosed Bus C37.23, IEEE USA, ISBN 978-15044-0650-5 (2015).

[6] K. Lukaszkowicz, L.A. Dobrzański, A. Zarychta, Structure, chemical and phase compositions of coatings deposited by reactive magnetron sputtering onto the brass substrate, Journal of Materials Processing Technology (2004), vols. 157-158, 380-387.

[7] B. Skowrońska, J. Szulc, T. Chmielewski, D. Golański, Wybrane właściwości złączy spawanych stali S700 MC wykonanych metodą hybrydową plazma+MAG, Welding Technology Review (2017), vol. 89 (10), 104-111.

[8] D. Golański, T. Chmielewski, B. Skowrońska, D. Rochalski, Advanced Applications of Microplasma Welding, Biuletyn Instytutu Spawalnictwa w Gliwicach (2018), vol. 62 (5), 53-63.

[9] B. Jaeschke, M. Węglowski, T. Chmielewski, Current State and Development Opportunities of Dynamic Power Source for GMA Welding Processes, Journal of Manufacturing Technologies (2017), vol. 42 (1), 23-30.

[10] K. Ferenc, P. Cegielski, T. Chmielewski, Technika spawalnicza w praktyce, Poradnik inżyniera konstruktora i technologa, Verlag Dashofer (2015), Warszawa.

[11] Welding Handbook, Metals and their weldability, American Welding Society (1972), The Sixth Edition, USA

[12] N. Izairi, F. Ajredini, A. Vevecka-Pfiftaj, P. Makreski, Ristova, Microhardness evolution in relation to the crystalline microstructure of aluminum alloy AA3004, Archives of Metallurgy Materials (2018), vol. 63 (3), 11011108.

[13] T.L. Giles, K. Oh-Ishi, A.P. Zhilyaev, S. Swami, M.W. Mahoney, T.R. McNelley, The Effect of Friction Stir Processing on the Microstructure and Mechanical Properties of an Aluminum Lithium Alloy, Metallurgical and Materials Transactions (2009), vol. 40 (1), 104-115.

[14] C. Hamilton, S. Dymek, A. Węglowska, A. Pietras, Numerical simulations for bobbin tool friction stir welding of aluminum 6082-T, Archives of Metallurgy Materials (2018), vol. 63 (3), 1115-1123.

[15] Y. Lin, Z. Zheng, S. Li., X. Kong, Y. Han, Microstructures and properties of 2099 Al-Li alloy, Materials Characterization (2013), vol. 84, 88-99.

[16] T. Węgrzyn, J. Piwnik, A. Silva, M. Plata, D. Hadryś, Micro-jet technology in welding, In Proceedings of the 23rd International Ocean (Offshore) and Polar Engineering Conference, Anchorage, AK, USA, 30 June - 5 July (2013), 178-180.

[17] B. Szczucka-Lasota, T. Węgrzyn, Z. Stanik, J. Piwnik, P. Sidun, Selected parameters of micro-jet cooling gases in hybrid spraying process, $\mathrm{Ar}$ chives of Metallurgy Materials (2016), vol. 61 (3), 621-624.

[18] D. Hadryś, Mechanical properties of plug welds after micro-jet cooling, Archives of Metallurgy Materials (2016), vol. 61 (4), 1771-1775.

[19] D. Hadryś, Impact load of welds after micro-jet cooling, Archives of Metallurgy Materials (2016), vol. 61, 2525-2528.

[20] R. Benato, F. Dughiero, M. Forzan, A. Paolucci, Proximity effect and magnetic field calculation in GIL and in isolated phase bus duct IEE Trans. of Magn. (2002), vol. 38 (2), 781-784.

(C) 2019 by the authors. Submitted for possible open access publication under the terms and conditions of the Creative Commons Attribution (CC BY) license (http://creativecommons.org/licenses/by/4.0/). 